

\section{NOTICE}

The submitted manuscript has been offered by an employee of the Alliance for Sustainable Energy, LLC (ASE), a contractor of the US Government under Contract No. DE-AC36-08-GO28308. Accordingly, the US Government and ASE retain a nonexclusive royalty-free license to publish or reproduce the published form of this contribution, or allow others to do so, for US Government purposes.

This report was prepared as an account of work sponsored by an agency of the United States government. Neither the United States government nor any agency thereof, nor any of their employees, makes any warranty, express or implied, or assumes any legal liability or responsibility for the accuracy, completeness, or usefulness of any information, apparatus, product, or process disclosed, or represents that its use would not infringe privately owned rights. Reference herein to any specific commercial product, process, or service by trade name, trademark, manufacturer, or otherwise does not necessarily constitute or imply its endorsement, recommendation, or favoring by the United States government or any agency thereof. The views and opinions of authors expressed herein do not necessarily state or reflect those of the United States government or any agency thereof.

Available electronically at http://www.osti.gov/bridge

Available for a processing fee to U.S. Department of Energy and its contractors, in paper, from:

U.S. Department of Energy

Office of Scientific and Technical Information

P.O. Box 62

Oak Ridge, TN 37831-0062

phone: 865.576 .8401

fax: 865.576 .5728

email: mailto:reports@adonis.osti.gov

Available for sale to the public, in paper, from:

U.S. Department of Commerce

National Technical Information Service

5285 Port Royal Road

Springfield, VA 22161

phone: 800.553.6847

fax: 703.605.6900

email: orders@ntis.fedworld.gov

online ordering: http://www.ntis.gov/ordering.htm 


\title{
SOLUTION DEPOSITION OF AMORPHOUS IZO FILMS BY ULTRASONIC SPRAY PYROLYSIS
}

\author{
Robert Pasquarelli ${ }^{1}$, Maikel van Hest ${ }^{2}$, Alexander Miedaner ${ }^{2}$, Calvin Curtis ${ }^{2}$, John Perkins ${ }^{2}$, Joseph Berry $^{2}$, \\ Ryan O'Hayre', David Ginley ${ }^{2}$ \\ ${ }^{1}$ Colorado School of Mines, Golden Colorado 80401 USA \\ ${ }^{2}$ National Renewable Energy Laboratory, Golden Colorado 80401 USA
}

\begin{abstract}
Atmospheric-pressure solution deposition of the transparent conducting oxide (TCO), amorphous indiumzinc oxide $(\alpha-\mid Z O)$, was investigated as an alternative to traditional vacuum-based physical vapor deposition techniques for photovoltaic applications. Solution processing is attractive due to its ease and potential to lower device manufacturing costs. Here we report on $\alpha$ IZO films prepared by ultrasonic spray pyrolysis from solutions of an indium-zinc formate (IZF) precursor. Thin, crack-free, amorphous IZO films with good optical transmittance $(>75 \%)$ and conductivities of $\sim 34 \mathrm{~S} / \mathrm{cm}$ were produced from an $\mathrm{IZF}-\mathrm{HNO}_{3}$-methanol ink using joint RTP and $\mathrm{Ar}-\mathrm{H}_{2}$ annealing.
\end{abstract}

\section{INTRODUCTION}

Currently, the thin film transparent conducting oxides (TCOs) used for CIGS are deposited by vacuum-based physical vapor deposition techniques such as sputtering. This study investigates atmospheric-pressure solution deposition routes as an alternative to these traditional high-vacuum techniques. Solution processing is attractive due to its ease and potential to lower device manufacturing costs.

$\mathrm{ZnO}$, typically used for the TCO layer, has poor resistance to water vapor. Recently, it has been demonstrated that amorphous indium-zinc oxide $(\alpha-I Z O)$ has qualitatively better resistance to degradation at $85^{\circ} \mathrm{C} /$ $85 \%$ relative humidity. Sputtered IZO shows the highest conductivity and smoothness in the indium-rich region ( 80 at $\%$ In) where the films are amorphous. However, current TCOs deposited by solution routes have only focused on crystalline, zinc-rich films (3-5 at\% In) [1-4]. In nearly all these cases, acetate precursors are used, but the high indium content of $\alpha-I Z O$ is difficult to achieve due to the poor solubility of indium acetate. Here we report on $\alpha-I Z O$ films prepared by ultrasonic spray pyrolysis from solutions of an indium-zinc formate (IZF) precursor. Thin, smooth, crack-free amorphous IZO films with good optical transmittance $(>75 \%)$ and conductivities of $\sim 34 \mathrm{~S} / \mathrm{cm}$ were produced from an IZF-HNO $\mathrm{HN}_{3}$-methanol ink using joint RTP and $\mathrm{Ar}-\mathrm{H}_{2}$ annealing.

\section{EXPERIMENTAL}

Indium-zinc formate (IZF) was prepared $(70: 30 \mathrm{~mol}$ $\mathrm{In}: \mathrm{Zn}$ ) using a synthesis procedure developed in our laboratory. The procedure and characterization of the precursor are subjects of a manuscript in progress. $0.1 \mathrm{M}$ IZF inks were prepared with $1 \mathrm{vol} \%$ of conc. $\mathrm{HNO}_{3}$ in both water and a methanol/water (10:1) mixture. Inks were aged 1-3 days and filtered prior to use. Films were ultrasonically sprayed in open atmosphere onto $\mathrm{O}_{2}$-plasma cleaned glass microscope slides mounted on a substrate heater and $X-Y$ stage. Typical deposition parameters were as follows: substrate surface temperatures $140-210^{\circ} \mathrm{C}, 7$ SLPM N $\mathrm{N}_{2}$ carrier flow, and a $0.25 \mathrm{~mL} / \mathrm{min}$ ink flow rate.

Films were aged for 2 days prior to annealing. Annealing was performed in a tube furnace under Ar$4 \% \mathrm{H}_{2}$ at $300^{\circ} \mathrm{C}$ for $20 \mathrm{~min}$ with a $3 \mathrm{hr}$ ramp. Additional samples were processed prior to anneal by rapid thermal processing (RTP) under Ar for $20 \mathrm{~min}$ at $340^{\circ} \mathrm{C}$ on a Si susceptor with a $20^{\circ} \mathrm{C} / \mathrm{sec}$ ramp film side up and then down.

\section{RESULTS AND DISCUSSION}

\section{Precursor Characterization and Ink Formulation}

The $\mathrm{In}: \mathrm{Zn}$ ratio for the prepared IZF was determined to be $70: 30$ at $\%$ by ICP-AES. This composition is near the peak conductivity of $80: 20$ for IZO. In order to determine the processing temperatures required to convert the IZF precursor into IZO, thermal gravimetric analysis (TGA) was performed in air. The decomposition temperature was determined to be $\sim 255^{\circ} \mathrm{C}$. Spraying was performed above the solvent boiling point but below the decomposition temperature. Annealing was performed at $300^{\circ} \mathrm{C}$ to ensure full decomposition.

The effect of additives to the ink not only influences ink properties (such as wetting) but also influences the ink chemistry. The addition of nitric acid was required to ensure solubility of the precursor. Nitric acid was chosen over other acids to promote oxide formation, as it is an oxidizing acid.

\section{Film Morphology and Optical Properties}

Sputtered IZO has been shown to be amorphous at a 70:30 In:Zn composition. XRD was performed to 
determine whether spray deposited films are amorphous as well. Fig. 1 shows that films annealed at $300^{\circ} \mathrm{C}$ are amorphous. Processing at higher temperature $\left(500^{\circ} \mathrm{C}\right)$ resulted in crystallization during decomposition and/or phase separation of $\ln _{2} \mathrm{O}_{3}$. Deposition temperature affected the morphology of the final films as spraying at $210^{\circ} \mathrm{C}$ showed greater resistance to $\ln _{2} \mathrm{O}_{3}$ formation.

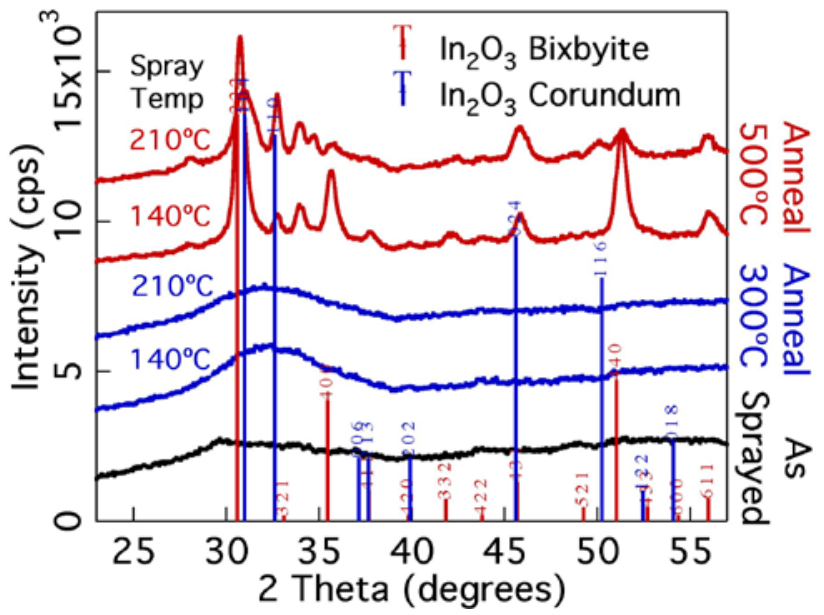

Fig. 1. XRD of sprayed films post-deposition at $140^{\circ} \mathrm{C}$ and $210^{\circ} \mathrm{C}$ and post-anneal at $300^{\circ} \mathrm{C}$ and $500^{\circ} \mathrm{C}$.

Transparency is a critical property for thin film transparent conductors. Film morphology is crucial in determining the optical properties of solution deposited films as cracks, pores, and surface roughness can result in scattering.

The ink solvent was found to affect the quality of the film produced. The water-based ink (Fig. 2a) resulted in a loss of optical transparency due to film cracking. However, the methanol/water mixed solvent (Fig. 2b) produced a crack free film with good optical properties. Little optical loss was observed after processing, with a respectable transmittance of $>75 \%$ as shown in Fig. 3 .

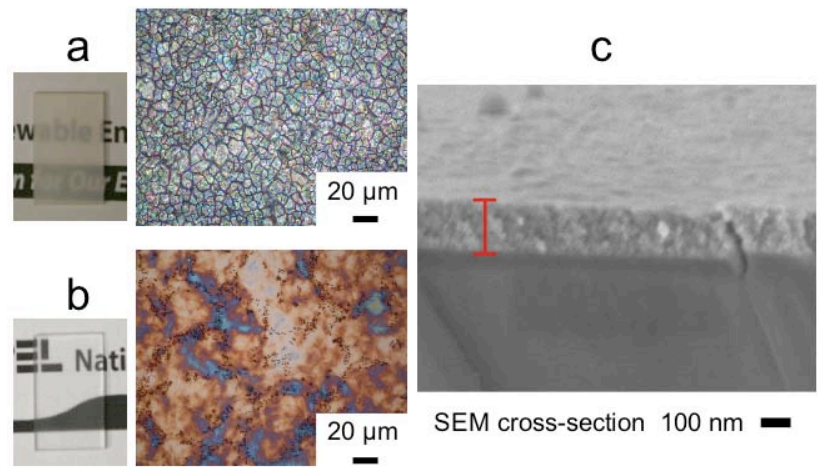

Fig. 2. Optical micrographs of films a) post-anneal sprayed from water-based ink, b) post-anneal sprayed from methanol/water-based ink, c) SEM cross-section of film post-anneal sprayed from methanol/water-based ink.
Spray depositing with 8 coats resulted in a smooth film with a thickness of $150-200 \mathrm{~nm}$ as seen in the SEM image in Fig. 2c. AFM studies are in progress to quantify the surface morphology and roughness.

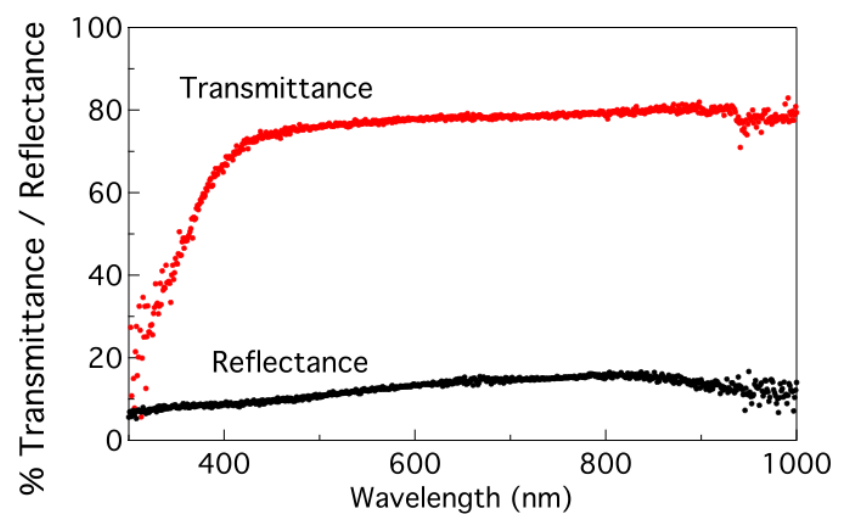

Fig. 3. Transmission-Reflectance of IZO film.

\section{Electrical Properties}

Conductivity is another critical property for thin film transparent conductors. Conductivity of the films was determined from 4-point probe sheet resistance and by Hall measurements. In general, it was observed that films sprayed at $210^{\circ} \mathrm{C}$ had higher conductivities.

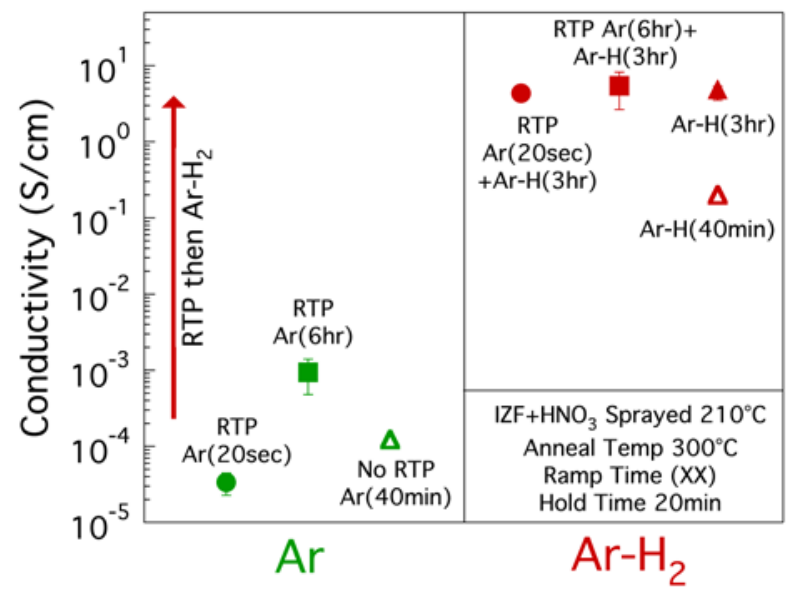

Fig. 4. Conductivity $(\sigma)$ of IZO films as a function of annealing gas and processing conditions. RTP denotes $\sigma$ after RTP step, and RTP+ denotes $\sigma$ after RTP and tube furnace anneal. Parenthesized value indicates ramp rate.

Fig. 4 shows the conductivity of films as a function of thermal processing atmosphere $\left(\mathrm{Ar}\right.$ and $\left.\mathrm{Ar}-4 \% \mathrm{H}_{2}\right)$, ramp time, and thermal processing scheme (RTP, tube furnace anneal, and RTP followed by a tube furnace anneal). First, conductivity increases with longer anneal times and with more reducing annealing atmospheres. This effect is attributed to the production of more carriers. Second, 
rapid thermal processing demonstrates promise as a quick production method for solution deposited TCOs. Lower conductivity films were observed because the RTP could only be performed under Ar flow in the current setup. More importantly, it was demonstrated that the conductivity could be increased by 4-5 orders of magnitude following a secondary $\mathrm{Ar}-\mathrm{H}_{2}$ anneal.

Fig. 5 compares the Hall conductivity (34 S/cm), carrier concentration $\left(8.5 \times 10^{19} \mathrm{\#} / \mathrm{cm}^{2}\right)$, and mobility $(2.0$ $\mathrm{cm}^{2} / \mathrm{Vs}$ ) of the best-sprayed IZO film to date with the typical property range for sputtered IZO (illustrated by bars). The carrier concentration and especially mobility each need to be increased by $\sim 1$ order of magnitude to be in range of sputtered IZO. The low mobility is attributed to porosity or small grains as seen in the SEM cross-section of the film (Fig. 2c).

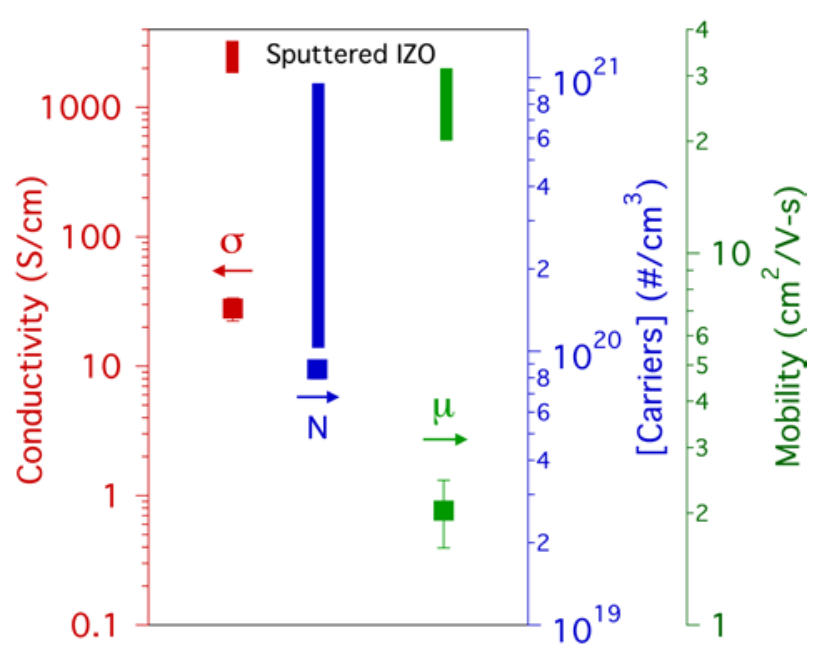

Fig. 5. Hall conductivity, carrier concentration, and mobility of best sprayed IZO film (points) compared to typical property range for sputtered IZO (bars).

\section{CONCLUSIONS}

In summary, In-Zn formate (IZF) can serve as an Inrich precursor for IZO films. Ultrasonic spray deposited

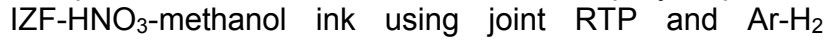
annealing results in thin, smooth, crack-free amorphous IZO films with good optical transmittance $(>75 \%)$. Current film conductivity $(\sim 34 \mathrm{~S} / \mathrm{cm})$ requires increases in both carrier concentration and mobility by $\sim 1$ order of magnitude to be comparable to sputtered IZO. Taken together, with the potential for lower production costs that solution processing offers, these attributes make ultrasonic spray deposited $\alpha-I Z O$ thin film TCOs an attractive choice for many PV applications.

\section{ACKNOWLEDGEMENTS}

This work was supported by the U.S. Department of Energy under Contract No. DOE-AC36-08G028308 with the National Renewable Energy Laboratory.

\section{REFERENCES}

[1] J. Wienke and A.S. Booij, "ZnO:In Deposition by Spray Pyrolysis - Influence of the Growth Conditions on the Electrical and Optical Properties," Thin Solid Films 516, 2008, pp. 4508-4512.

[2] S.-Y. Lee and B.-O. Park, "Electrical and Optical Properties of In2O3-ZnO Thin Films Prepared by Sol-gel Method," Thin Solid Films 484, 2005, pp. 184-187.

[3] M. de la L. Olvera, H. Gomez, and A. Maldonado, "Doping, Vacuum Annealing, and Thickness Effect on the Physical Properties of Zinc Oxide Films Deposited by Spray Pyrolysis," Solar Energy Materials \& Solar Cells 91, 2007, pp. 1449-1453.

[4] C.G. Choi, S.-J. Seo, and B.-S. Bae, "SolutionProcessed Indium-Zinc Oxide Transparent Thin-Film Transistors," Electrochemical and Solid-State Letters 11 (1), 2008, pp. H7-H9. 


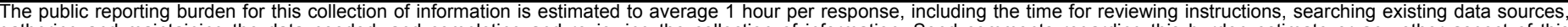

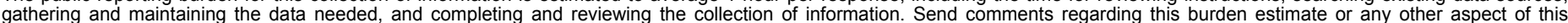

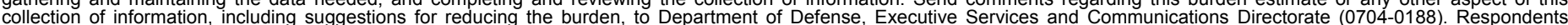

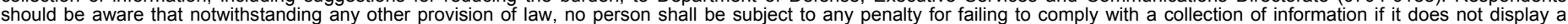

should be aware that notwithstanding

PLEASE DO NOT RETURN YOUR FORM TO THE ABOVE ORGANIZATION.

\section{REPORT DATE (DD-MM-YYYY) June 2009

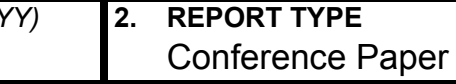 \\ \begin{tabular}{l|l} 
2. & REPORT TYPE \\
& Conference Paper
\end{tabular}}

4. TITLE AND SUBTITLE

Solution Deposition of Amorphous IZO Films by Ultrasonic Spray

Pyrolysis: Preprint

\author{
3. DATES COVERED (From - To) \\ June 7-12, 2009 \\ 5a. CONTRACT NUMBER \\ DE-AC36-08-GO28308
}

5b. GRANT NUMBER

5c. PROGRAM ELEMENT NUMBER

5d. PROJECT NUMBER

NREL/CP-520-46016

5e. TASK NUMBER

PVA92810

5f. WORK UNIT NUMBER
7. PERFORMING ORGANIZATION NAME(S) AND ADDRESS(ES)

National Renewable Energy Laboratory

1617 Cole Blvd.

Golden, CO 80401-3393

9. SPONSORING/MONITORING AGENCY NAME(S) AND ADDRESS(ES)
8. PERFORMING ORGANIZATION REPORT NUMBER
NREL/CP-520-46016

10. SPONSOR/MONITOR'S ACRONYM(S) NREL

11. SPONSORING/MONITORING AGENCY REPORT NUMBER

12. DISTRIBUTION AVAILABILITY STATEMENT

National Technical Information Service

U.S. Department of Commerce

5285 Port Royal Road

Springfield, VA 22161

13. SUPPLEMENTARY NOTES

14. ABSTRACT (Maximum 200 Words)

Atmospheric-pressure solution deposition of the transparent conducting oxide (TCO), amorphous indium-zinc oxide $(\alpha-I Z O)$, was investigated as an alternative to traditional vacuum-based physical vapor deposition techniques for photovoltaic applications. Solution processing is attractive due to its ease and potential to lower device manufacturing costs. Here we report on $\alpha-I Z O$ films prepared by ultrasonic spray pyrolysis from solutions of an indium-zinc formate (IZF) precursor. Thin, crack-free, amorphous IZO films with good optical transmittance (>75\%) and conductivities of $\sim 34 \mathrm{~S} / \mathrm{cm}$ were produced from an IZF-HNO 3 -methanol ink using joint RTP and $\mathrm{Ar}-\mathrm{H}_{2}$ annealing.

\section{SUBJECT TERMS}

PV; solution deposition; atmospheric pressure; transparent conducting oxides; amorphous indium zinc-oxide; vapor deposition; spray pyrolysis; rapid thermal processing;

\begin{tabular}{|l|l|l|l|l|}
\hline 16. SECURITY CLASSIFICATION OF: & $\begin{array}{c}\text { 17. LIMITATION } \\
\text { OF ABSTRACT } \\
\text { a. REPORT } \\
\begin{array}{l}\text { Unclassified } \\
\text { Unclassified }\end{array}\end{array}$ & $\begin{array}{l}\text { b. ABSTRACT } \\
\text { Unclassified }\end{array}$ & $\begin{array}{c}\text { NUMBER } \\
\text { OF PAGES }\end{array}$ \\
\hline
\end{tabular}

19a. NAME OF RESPONSIBLE PERSON

19b. TELEPHONE NUMBER (Include area code) 